\title{
A Radioimmunoassay System for Human Serum Cortisol
}

\author{
Kh.M.Sallam ${ }^{l}$, Nabila Zein ${ }^{2}$, A.S.A.Elbayoumy ${ }^{1}$, N.H.Ebeid ${ }^{l}$, E.Michael ${ }^{l}$, Ah.F.Elfaragy ${ }^{2}$ \\ ${ }^{1}$ Labelled Compounds Dept., Hot Labs Center, Atomic Energy Authority,Cairo, Egypt \\ ${ }^{2}$ Chemistry Department, Faculty of Science, Zagazig University, Egypt
}

\begin{tabular}{l}
\hline A R T I C L E I N F O \\
Keywords: \\
$\begin{array}{l}\text { Cortisol, Immunization, Polyclonal } \\
\text { antibodies, Radioimmunoassay } \\
125 \text { I, Liquid phase. }\end{array}$ \\
Abbreviations \\
RIA Radioimmunoassay \\
C-21-hs:BSA cortisol-21- \\
hemisuccinate:Bovine serum albumin \\
PEG Polyethelene glycol \\
NRS non-immunized rabbit serum
\end{tabular}

\begin{abstract}
A B S T R A C T
Background: Cortisol (hydrocortisone) is the most potent glucocorticoid produced by the human adrenal cortex with about 55-69 $\mu \mathrm{mol}(20-25 \mathrm{mg})$ released daily, and the rate of release has a pronounced diurnal rythm. The plasma concentration is highest in the early morning around 06:00 $(140-700 \mathrm{nmol} / \mathrm{L})$, while the nadir is about midnight $(\sim 250 \mathrm{nmol} / \mathrm{L})$. Cortisol acts through specific intracellular receptors and has effects in numerous physiologic systems, including immune function, glucosecounter regulation, vascular tone, substrate utilization and bone metabolism. For accurate detection of this low concentration of cortisol in human serum, Radioimmunoassay (RIA) is used; which is known as the most recognized sensitive microanalytical technique for the determination of the very low concentrations of awide range of substances of biological and medical interest. No other analytical method can reach the low detection limits of assayed analytes attained by RIA realted techniques.Applicability, simplicity, to operate and economy of RIA have paved the way for the last advancement in medical research during the past five decades. Materials \& Methods: Highly purified Hydrocortisone-21-hemisuccinate and Bovine Serum Albumin used to prepare immunogen (cortisol-21-hemisuccinate: BSA), which is immunized into rabbits to produce cortisol polyclonal antibodies, $\mathrm{Na}{ }^{125} \mathrm{I}$ $(370 \mathrm{MBq} / 100 \mu \mathrm{l})$ carrier and reductant free is the radioactive material used to prepare the tracer (Institute of Isotopes Co.,Hungary). All above materials in addition to prepared standards of cortisol used to prepare radioimmunoassay system to assess cortisol level. Objective: This work was carried to assess and development the technical as well as the economic feasibility of establishing local radioimmunoassay for human serum cortisol. Results: immunogen obtained was of 17 cortisol molecule : 1 BSA molecule ,the dilution of the antibody was chosen to be $1 / 8000$ according to the best displacement percent $(76.5 \%)$ obtained at this dilution from the the $5^{\text {th }}$ bleed of the $1^{\text {st }}$ rabbit in group A and the prepared tracer was of radiochemical yield percent $(58.5 \%)$, radiochemical purity (96\%)and specific activity $(120 \mu \mathrm{Ci} / \mu \mathrm{g})$
\end{abstract}

Conclusion: This RIA-technique method for detection of cortisol level in human serum is simple, accurate and can be used as a decisive diagnostic tool for adrenal status.

(C) 2015 Publisher All rights reserved.

\section{INTRODUCTION}

Cortisol helps control carbohydrate, protein, and lipid metabolism. For example, cortisol increases glucose level in the blood by stimulating gluconeogenesis in the liver and promotes the formation of glycogen (i.e., a molecule that serves as the storage form of glucose) in the liver. Cortisol also reduces glucose uptake into muscle and adipose tissue, 
thereby opposing the effects of insulin ${ }^{[1.2]}$. Furthermore, in various tissues, cortisol promotes protein and lipid breakdown into products (i.e., amino acids and glycerol, respectively) that can be used for gluconeogenesis ${ }^{[3]}$. In addition to those metabolic activities, cortisol appears to protect the body against the deleterious effects of various stress factors, including acute trauma, major surgery, severe infections, pain, blood loss, hypoglycemia, and emotional stress ${ }^{[4]}$. Plasma cortisol level is widely used as an indicator of stress ${ }^{[5]}$.

There are wide variations in cortisol blood levels throughout the day. The typical circadian rhythm of cortisol secretion can be correlated to the activity of the cerebral centres and the pituitary. Cortisolaemia reaches a maximum in the early morning hours, then it shows a sharp decrease during the afternoon and the evening; the lowest level is reached about midnight. It is obvious that cortisol assay on a single blood sample taken at random during the day does not give useful indications about the functional behaviour of the adrenal cortex ${ }^{[6.7]}$.

Moreover, it must be remembered that the blood level of a hormone does not depend only on the amount secreted by the gland cells, but also on the circulating carrier protein, the distribution of the hormone and the clearance rate from the blood due to both hepatic catabolism and renal excretion. Inspite of this, cortisol determination in plasma samples taken at a fixed time (e.g. 8-9 a.m) gives very useful information about gross impairment of adrenals, thus constituting an essential screening tool.

Elevated cortisol levels and lack of diurnal variation have been identified in patients with Cushing's disease (ACTH hypersecretion) ${ }^{[\mathbf{8 , 9}]}$. Elevated circulating cortisol levels have also been identified in patients with adrenal tumors ${ }^{[1]}$. Low cortisol levels are found in primary adrenal insufficiency (e.g. adrenal hypoplasia, congenital adrenal hyperplasia, Addison's disease) and in ACTH deficiency ${ }^{[8,2,10]}$.

Radioimmunoassay (RIA) is known as the most recognized sensitive microanalytical technique for the determination of the very low concentrations of a wide range of substances of biological and medical interest. No other analytical method can reach the low detection limits of assayed analytes attained by RIA realted techniques. Applicability, simplicity, to operate and economy of RIA have paved the way for the last advancement in medical research during the past five decades ${ }^{[11]}$.

\section{MATERIALS AND METHODS \\ (I) Materials:}

Highly purified Hydrocortisone21-hemisuccinate, analytical standard : H2882, Fluka, Bovine Serum AlbuminFraction V, lyophilized powder Purity $\geq$ 98\% :85040C, Sigma-Aldrich,USA, complete and incomplete freunds adjuvant, chloramine-T, sodium metabisulphite ,polyethelyne glycol 8000(PEG), Goat anti-rabbit IgG (whole molecule) purchased from Sigma-Aldrich, USA, $\mathrm{NaI}^{125}(370 \mathrm{MBq} / 100 \mu \mathrm{l})$ carrier and reductant free (Institute of Isotopes Co.,Hungary).

Chemicals: All chemicals used in these experiments were provided from Sigma Chemical Co. of high quality and purity.

\section{(II) Methods:}

\section{Preparation of Hydrocortisone-21- hemisuccinate : BSA}

Hydrocortisone-bovine serum albumin conjugate (C-21-hs:BSA) was prepared by the mixed anhydride procedure according to Erlanger et al., $1957,1958{ }^{[12.13]}$ with some modifications using Highly purified Hydrocortisone-21-hemisuccinate and Bovine Serum Albumin at the C-21 position 


\section{Production of cortisol polyclonal antibodies:}

Production of cortisol polyclonal antibody was undertaken through immunization of eight male mature white New-Zealand rabbits weighing $2-3 \mathrm{~kg}$ with the prepared antigen. Rabbits classified into two groups the first group comprised six rabbits (R1-R6) and the second group comprised two rabbits (R7R8). They were kept under the same hygienic conditions, well balanced diet and water supply. The local production of polyclonal antibody was carried out through primary and boosters immunizations.

For primary immunization: each rabbit in the first group received $1000 \mu \mathrm{g}$ of immunogen in $1 \mathrm{ml}$ emulsion. While, each rabbit in the second group received $200 \mu \mathrm{g}$ of the immunogen in $1 \mathrm{ml}$ emulsion.

For boosters: each rabbit in the first group received $500 \mu \mathrm{g}$ of the immunogen in 0.5 $\mathrm{ml}$ emulsion. While, each rabbit in the second group received $100 \mu \mathrm{g}$ of the immunogen in $0.5 \mathrm{ml}$ emulsion.

For emulsion preparations Freund's adjuvant complete (FAC) was used for primary injection and Freund's adjuvant incomplete (FAI) was used for booster doses (Jacobs, 1974, Goding, 1986, Pillai and Bhandarkar, 1998)." $(26,27,28)^{[}$]

Emulsification was performed using Hamilton double hub syringes connected to each other with narrow metallic tubing. The aqueous solution was placed in one syringe and the adjuvant in the other one. The aqueous solution was forced through the tube into the oil in other syringe; then, the mixture was forced back and front until a stable water-in-oil emulsion was formed. Immunization takes place according to the following schedules :

Five injections were administrated, one primary and four booster injections, at 4 weeks interval and Blood samples were collected three weeks after each injection

Each bleed tested for cortisol antibody. Anti-sera obtained were assessed in terms of: titer, displacement, immunoresponse.

\section{Preparation of radio-iodinated cortisol tracer:}

The preparation of radiolabelled Hydrocortisone-21-hemisuccinate: BSA using radioactive ${ }^{125} \mathrm{I}$ was carried out according to Midgley et al;1969 ${ }^{[14]}$ and Jeffcoate et al.,1972 [15] with slight modification using chloramine-T method as described by Hunter and Greenwood $1962^{[16]}$.

\section{Preparation of cortisol standards}

$10 \mathrm{mg}$ of highly purified Cortisol were dissolved in $10 \mathrm{ml}$ of ethanol to get a concentration of $1 \mathrm{mg} / \mathrm{ml}$. A stock solution of $1 \mu \mathrm{g} / \mathrm{ml}$ was prepared using steroid assay buffer. The serial dilutions were made to obtain different concentrations ranged from $0.5-60 \mu \mathrm{g} / \mathrm{dl}$ using steroid assay buffer. Prepared standard were kept at $4{ }^{\circ} \mathrm{C}$.

\section{Preparation of double- antibody liquid phase RIA system}

Radioimmunoassay of cortisol was carried out as follow: $100 \mu \mathrm{l}$ of standards or unknown samples and $100 \mu \mathrm{l}$ of cortisol tracer were incubated with $100 \mu \mathrm{l}$ anticortisol for $3 \mathrm{~h}$ at R.T . The separation of bound and free fractions was carried out by incubation with $700 \mu \mathrm{l}$ of precipitating agent which contains $100 \mu \mathrm{l}$ 2nd antibody (goat anti-rabbit IgG) ,100 $\mu 1$ nonimmunized rabbit serum (NRS) and $500 \mu \mathrm{l}$ polyethylene glycol (PEG) (8000,12\%) into all assay tubes ${ }^{[17]}$. the supernatant was decanted after centrifugation and the bound fraction was counted using gamma counter.

\section{Optimization of the liquid-phase RIA system:}

To optimize the liquid phase RIA system under investigation the optimum assay conditions were performed by studying four important factors: temperature, incubation time, sample volume, and separating agents. 
Effect of temperature: The effect of temperature on the local liquid phase RIA for cortisol using three different temperature degrees $\left(4{ }^{\circ} \mathrm{C}\right.$, Room Temp. $25{ }^{\circ} \mathrm{C}$ " and $37{ }^{\circ} \mathrm{C}$ ) for 3 hours was studied . Effect of incubation time The effect of incubation time on the local liquid phase RIA of cortisol was carried out through out $24 \mathrm{hrs}$, ranged from one hour to $24 \mathrm{hrs}$, all at $37{ }^{\circ} \mathrm{C}$. Effect of sample volume Different sample volumes were tested Effect of separating agents Different dilutions of goat anti-rabbit $\operatorname{IgG}\left(2^{\text {nd }}\right.$ antibody), non-immune rabbit serum and different concentrations of PEG-8000 were studied for the best displacement

Standard curve representation: standard curve for Cortisol represented by measuring the $\mathrm{B} / \mathrm{B} 0$ value for each standard value from zero to $60 \mu \mathrm{g} / \mathrm{dl}$.

\section{Validation of cortisol radioimmunoassay} system: To assure the validity and reliability of the proposed assay some performance characteristics studies, included sensitivity, specificity, precision, accuracy (recovery and dilution tests) must be studied

\section{RESULTS}

For the polyclonal antibodies produced, the data obtained from studying titer and displacement for each bleed of each rabbit showed that the antisera obtained from bleeding five of rabbit one in group A (R1) gave the highest displacement percent (76.5 \%) with binding (43.2\%) at dilution 1:8000 which is chosen to complete the assay using it.

For the tracer prepared, the radiochemical yield percent of the prepared tracer was found to be $58.5 \%$ (Fig. 1), also the radiochemical purity percent was determined on paper electrophoresis and it was found to be $96 \%$ (Fig. 2), the specific activity of the prepared tracer was 120 $\mu \mathrm{Ci} / \mu \mathrm{g}$.

Optimum conditions detected are summarized in (Tab. 1)For the temperature: The highest differences in percent binding between the studied concentrations were proved using temperature at $37{ }^{\circ} \mathrm{C}$. For incubation time: The data obtained for $3 \mathrm{hrs}$ incubation are optimum. For sample volume: The highest differences in displacement between the concentrations of cortisol were demonstrated using $100 \mu 1$ as a sample volume. For separating agents: Results showed that the optimum dilutions were 1:80, 1:200 for $2^{\text {nd }}$ antibody and non-immune rabbit serum respectively and $500 \mu \mathrm{l}$ of $12 \%$ concentration of PEG8000

These optimum conditions used to draw an optimum standard curve (Fig. 3) which is used to identify concentrations of unknown samples of cortisol.

\section{Validation of the liquid-phase RIA system}

Sensitivity: A detection limit of $0.11 \mu \mathrm{g} / \mathrm{dl}$ has been obtained by assaying 20 replicates of the zero standard. The sensitivity has been determined as the concentration corresponding to mean count per minute minus its double standard deviation (Tab. 2).

Precision: It is a statistical index of the ability of an assay to yield the same result when the assay is repeated on the same sample through two methods: intra-assay precision (within run) which was determined by taking samples and running these samples multiple times in the same assay and inter-assay precession (Run to run) which was determined by measuring the same samples in multiple assays (Tab.3,4)

Accuracy: Accuracy assessment of the assay under investigation was carried out throughout recovery and dilution tests (parallelism)

Recovery test: The recovery test measures the concentration in human samples before and after adding known samples of pure analyte (cortisol) the recovery data of this study (Tab. 5) are in good agreement with 
the data of Pilliai and Bhandarkar $1998^{[18]}$ and El-kolaly et al.2006 ${ }^{[19]}$ who stated that the recovery of the assay should be $100 . \pm 15 \%$.

Dilution test : The results in (Tab. 6) reveal the concentrations of three human samples undiluted and at various dilutions in the matrix of the assay to assess the linearity of the assay. Edwards, $1996^{[20]}$ reported that non-linearity indicated inaccurate calibration or an inappropriate matrix or both.

Specificity (cross-reactivity): Specificity is expressed as cross reactivity and interference with high concentrations of related hormones such as (progesterone, Estradiol, Testesterone) (Tab. 7)

\section{DISCUSSION:}

Measurement of cortisol hormone in serum is an important tool for the diagnosis of adrenal status.

We use radioimmunoassay method in this study because it is an elegant technique used in measurement of very low concentrations of specific compounds in the presence of excess of other materials

The present study was motivated by many factors as the commercial importance, the kit manufacturers don't disclose the details of the technique and also there is a lack of literature in respect to details of these technique. So, local preparation and evaluation of reagents and establishment of the liquid phase RIA technique becomes necessary.

Therefore, the aim of the present study was oriented to optimize the procedure used for determination of cortisol level in human sera. The research plan of this work was designed to achieve the following:

Preparation of the immunogen (Hydrocortisone-21-hemisuccinate: BSA) this is because cortisol has haptenic nature, so, it must be linked by accepted ratio to protein which can provoke the immune system of the host animal.
We choose BSA because of its availability and fast solubility in partial organic/aqueous solvent system ${ }^{\text {[21] }}$

The ratio of attachement of cortisol residue to BSA was in the acceptable range (17 molecule cortisol / 1 molecule BSA) ${ }^{[11.12]}$. Preparation of the basic reagents of cortisol assay which comprised of: polyclonal antibodies, radiolabelled cortisol tracer and cortisol standards.

results obtained in the step of production of polyclonal antibodies are in good agreement with many reports ${ }^{[18,22]}$

At the same time the preparation of ${ }^{125} \mathrm{I}$ Cortisol tracer of high radiochemical purity and immunoreactivity is essential for the development of sensitive, precise and accurate radioimmunoassay technique The results of the present work revealed that ${ }^{125}$ I-Cortisol tracer yield was $58.5 \%$ and purity $96 \%$ with specific activity 120 $\mu \mathrm{Ci} / \mu \mathrm{g}$. therefore, the chloramines- $\mathrm{T}$ oxidation method was found to be the suitable and fast technique which give high yield, stable and pure tracer

Third component was cortisol standards which was prepared and calibrated to be used for preparing the standard curve as the main components were prepared, the development of double antibody radioimmunoassay system for the measurement of cortisol in human serum was performed by studying four important factors (temperature, incubation time, sample volume and precipitating agents) and to assure the validity of the local double antibody RIA technique, some performance characteristics studies were carried out. As : sensitivity, precision (intra and inter- assay), accuracy (recovery and dilution tests) and specificity

\section{CONCLUSION}

In conclusion, the technical simplicity of this sensitive, precise and accurate method may suggest that this cortisol-RIA technique should be suited for routine laboratory uses and can be used effectively as a decisive diagnostic tool for adrenal status. 
Table(1) : Optimum conditions used to draw the standard curve was:

\begin{tabular}{||c|c|c|c||}
\hline \hline Dilution of antibody & $\begin{array}{c}\text { Incubation } \\
\text { temperature }\end{array}$ & $\begin{array}{c}\text { Incubation } \\
\text { time }\end{array}$ & $\begin{array}{c}\text { Sample } \\
\text { volume }\end{array}$ \\
\hline $1 / 8000$ of R1 bleed 5 & $37 \mathrm{C}$ & $3 \mathrm{~h}$ & $100 \mu \mathrm{l}$ \\
\hline PEG concentration & PEG volume & $\begin{array}{c}\text { Second } \\
\text { antibody }\end{array}$ & $\begin{array}{c}\text { Non-immune } \\
\text { rabbit serum }\end{array}$ \\
\hline $12 \%$ & $500 \mu \mathrm{l}$ & $1: 80$ & $1: 200$ \\
\hline
\end{tabular}

Table(2) : The sensitivity of cortisol liquid phase RIA system

\begin{tabular}{||c||c||c||c||c||}
\hline $\begin{array}{c}\text { Cpm } \\
(\mathbf{m e a n}-S D)\end{array}$ & $\begin{array}{c}\text { Cpm } \\
(\mathbf{m e a n}-2 S D)\end{array}$ & B/Bo \% & $\begin{array}{c}\text { Apparent } \\
\text { Concentration } \\
(\boldsymbol{\mu g} / \mathbf{d l})\end{array}$ & $\begin{array}{c}\text { Approximate } \\
\text { Sensitivity }(\boldsymbol{\mu g} / \mathbf{d l})\end{array}$ \\
\hline \hline $10239-112.95$ & $10239-225.9$ & 95.1 & 0.11 & 0.11 \\
\hline
\end{tabular}

Table(3) : Intra-assay precision for Cortisol using liquid phase RIA system

\begin{tabular}{|c|c|c|c|}
\hline \multirow[b]{2}{*}{ Samples } & \multicolumn{3}{|c|}{ Intra-assay } \\
\hline & $\begin{array}{r}\text { Mean } \\
(\mu \mathrm{g} / \mathrm{dl})\end{array}$ & $\begin{array}{c}\text { SD } \\
(\mu \mathrm{g} / \mathrm{dl})\end{array}$ & CV\% \\
\hline Low & 2.35 & 0.14 & 6.1 \\
\hline Normal & 8.1 & 0.29 & 3.6 \\
\hline High & 13.2 & 1.10 & 8.4 \\
\hline
\end{tabular}

Table(4) : Intra-assay precision for Cortisol using liquid phase RIA system

\begin{tabular}{|c|c|c|c|}
\hline \multirow[b]{2}{*}{ Samples } & \multicolumn{3}{|c|}{ Intra-assay } \\
\hline & $\begin{array}{r}\text { Mean } \\
(\mu \mathrm{g} / \mathrm{dl})\end{array}$ & $\begin{array}{c}\text { SD } \\
(\mu \mathrm{g} / \mathrm{dl})\end{array}$ & CV\% \\
\hline Low & 2.58 & 0.20 & 7.6 \\
\hline Normal & 7.95 & 0.55 & 6.9 \\
\hline High & 13.4 & 1.26 & 9.4 \\
\hline
\end{tabular}


Table(5) : Recovery assessment for cortisol using liquid phase RIA system.

\begin{tabular}{|c|c|c|c|c|c|}
\hline Sample & $\begin{array}{c}\text { Endogenous } \\
(\mu \mathrm{g} / \mathrm{dl})\end{array}$ & $\begin{array}{l}\text { Added } \\
(\mu g / d l)\end{array}$ & $\begin{array}{c}\text { Expected } \\
(\mu \mathrm{g} / \mathrm{dl})\end{array}$ & $\begin{array}{c}\text { Observed } \\
(\mu \mathrm{g} / \mathrm{dl})\end{array}$ & $\begin{array}{c}\text { Recovery } \\
(\%)\end{array}$ \\
\hline \multirow{3}{*}{1} & \multirow{3}{*}{2.47} & 1.92 & 2.20 & 2.18 & 99.25 \\
\hline & & 3.84 & 3.16 & 3.50 & 110.98 \\
\hline & & 7.68 & 5.08 & 4.65 & 91.7 \\
\hline \multirow{3}{*}{2} & \multirow{3}{*}{8.14} & 1.92 & 5.03 & 4.40 & 87.48 \\
\hline & & 3.84 & 5.99 & 6.10 & 101.81 \\
\hline & & 7.68 & 7.91 & 7.31 & 92.41 \\
\hline \multirow{3}{*}{3} & \multirow{3}{*}{13.31} & 1.92 & 7.62 & 7.30 & 95.82 \\
\hline & & 3.84 & 8.58 & 7.67 & 89.49 \\
\hline & & 7.68 & 10.50 & 9.14 & 87.08 \\
\hline
\end{tabular}

Table (6): Dilution test for cortisol using liquid phase RIA system.

\begin{tabular}{|c|c|c|c|c|c|}
\hline Sample & $\begin{array}{c}\text { Endogenous } \\
(\mu \mathrm{g} / \mathrm{dl})\end{array}$ & $\begin{array}{l}\text { Dilution } \\
\text { factor }\end{array}$ & $\begin{array}{c}\text { Expected } \\
(\mu g / d L)\end{array}$ & $\begin{array}{c}\text { Observed } \\
(\mu \mathrm{g} / \mathrm{dL})\end{array}$ & $\begin{array}{c}\text { Recovery } \\
(\%)\end{array}$ \\
\hline \multirow{4}{*}{1} & \multirow{4}{*}{2.47} & $1: 2$ & 1.24 & 1.10 & 88.68 \\
\hline & & $1: 4$ & 0.62 & 0.53 & 86.45 \\
\hline & & $1: 8$ & 0.31 & 0.24 & 76.3 \\
\hline & & $1: 16$ & 0.15 & 0.12 & 78.24 \\
\hline \multirow{4}{*}{2} & \multirow{4}{*}{8.14} & $1: 2$ & 4.07 & 4.09 & 100.5 \\
\hline & & $1: 4$ & 2.04 & 1.93 & 94.97 \\
\hline & & $1: 8$ & 1.02 & 1.08 & 106.61 \\
\hline & & $1: 16$ & 0.51 & 0.55 & 107.47 \\
\hline \multirow{4}{*}{3} & \multirow{4}{*}{13.31} & $1: 2$ & 6.66 & 6.43 & 96.67 \\
\hline & & $1: 4$ & 3.33 & 3.06 & 92.08 \\
\hline & & $1: 8$ & 1.66 & 1.42 & 85.55 \\
\hline & & $1: 16$ & 0.83 & 0.70 & 84.55 \\
\hline
\end{tabular}

Table(7): specificity (cross-reactivity) of the anti-cortisol using liquid phase RIA

\begin{tabular}{|c||c||}
\hline Steroid & Cross Reactivity \% \\
\hline \hline Cortisol & 100 \\
\hline Testosterone & 0.17 \\
\hline Progesterone & 0.13 \\
\hline Estradiol & 0.04 \\
\hline
\end{tabular}




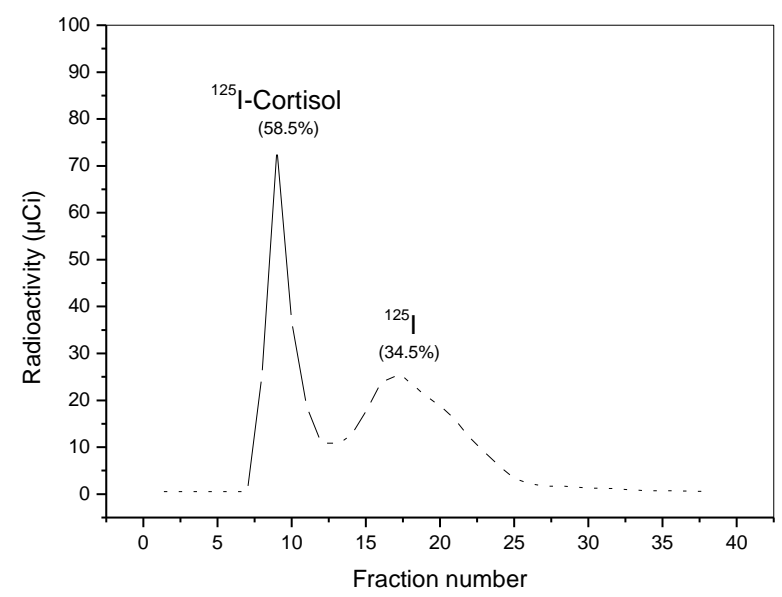

Figure(1): Elution pattern of radioiodination mixture of cortisol and purification of ${ }^{125} \mathrm{I}$ - cortisol tracer using gel chromatography on sehadexG-25

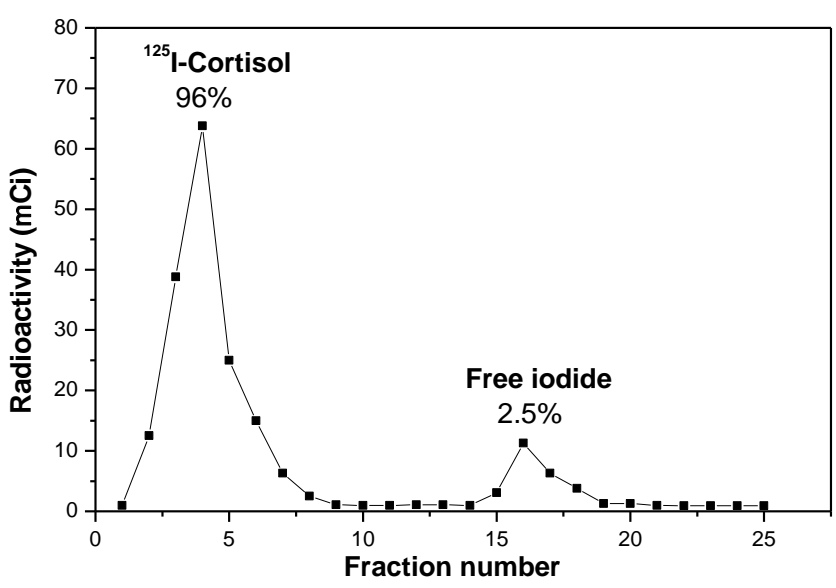

Figure(2): Electrophoretical pattern of radiochemical purity of produced ${ }^{125} \mathrm{I}$-Cortisol tracer

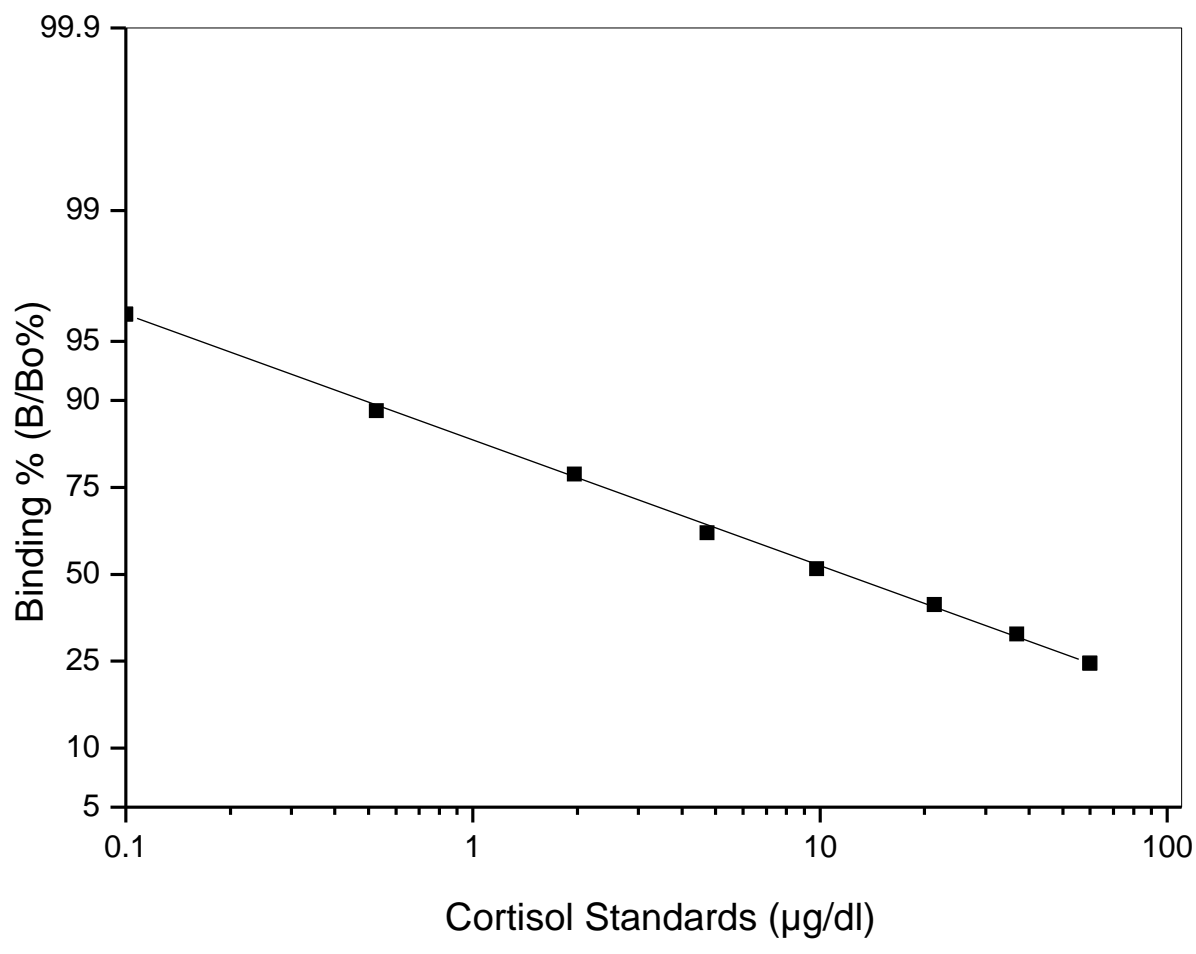

Figure(3): Optimized standard curve for cortisol using liquid phase RIA system. 


\section{References}

1- Brown DF., Brown DD., (2003); "USMLE Step 1 Secrets: Questions You Will Be Asked on USMLE Step 1"; Philadelphia: Hanley \& Belfus; 63.

2- $\quad$ King M., (2005); " Lange Q \& A."; McGraw-Hill, Medical Pub. Division.

3- Manchester, KL., (1964); "Sites of Hormonal Regulation of Protein Metabolism " in " Mammalian Protein Metabolism ", Allison, NH \& Munro JB., (eds). Academic Press .; 229-273.

4- Goulding N.J. \& Flower R.J., (2001); "Glucocorticoids (Milestones in Drug Therapy)"; Birkhauser; $1^{\text {st }}$ ed.

5- Jones C., (1957); "The Adrenal Cortex"; Cambridge University Press.;

6- Veldhuis J. D., Iranmanesh A., Johnson M. L., Lizarralde G., (1990); "Amplitude, but not frequency, modulation of adrenocorticotropin secretory bursts gives rise to the nyctohemeral rhythm of the corticotropic axis in man "; J. Clin. Endocrinol. Metab.; 71 ,452-463.

7- Young E.A., Abelson J., Lightman S. L., (2004); "Cortisol pulsatility and its role in stress regulation and health "; Front Neuroendocrinol; 25 ,69-76.

8- Tepperman J., (1968); "Metabolic and Endocrine Physiology"; Yearbook Medical Publishers .; $2^{\text {nd }}$ ed.

9- Robert Fraser, D.B. Gower, John W. Honour, Mary C. Ingram, Andrew T. Kicman, Hugh L.J. Makin and Paul M. Stewart., (2010); "Analysis of Corticosteroids" in " Steroid analysis, $2^{\text {nd }}$ ed.", H.L.J.Makin, D.B.Gower, Springer; 329.

10- Elenkov IJ., (2004); "Glucocorticoids and the Th1/Th2 Balance "; Annals of the New York Academy of Sciences.; 1024 (1),138-146.

11- Daci, B.; Malja, S. and Bylyku, E.: Fifth General Conference of Balkan Physical Union, Vrnaeka Banja, Serbia and Montenegra, 2176-2193, (2003).

12- Bernard F. Erlanger, Felix Borek, Sam M. Beiser and Seymour Lieberman., (1957); "preparation and characterization of conjugates of bovine serum albumin with testosterone and with cortisone"; J. Biol. Chem.; 228 ,713-728.

13- Bernard F. Erlanger, Felix Borek, Sam M. Beiser and Seymour Lieberman, (1959); "preparation and characterization of conjugates of bovine serum albumin with progesterone, deoxycorticosterone, and estrone"; J. Biol. Chem.; 234 ,1090-1094

14- A. Rees Midgley, Jr., G.D. Niswender, and J. Sri Ram (1969) " haptenradioimmunoassay: a general procedure for the estimation of steroidal and other haptenic substances " Academic Press.

15- Jeffcoate,S.L., GilbyE.D.,andEdwards,R.,(1973), The preparation and use of ${ }^{125}$ I steroidalbumin conjugates as tracers in steroid immunoassay.Clin.Chim.Acta 43,343-349

16- Hunter W M and Greenwood F C., (1962); "Preparation of iodine - 131 labeled human growth hormone of high specific activity "; Nature; 194,495 - 496.

17- Mehany, N.L., El-Kolaly, M.T., El-Hashash, M.A. and Sallam, Kh.M., (2007), Arab. J.Nucl. Sci. Appl., 40, 1, 299.

18- Pilliai, M.R.A and Bahandarker, S.D., (1998), In: Radioimmnoassay Principle and Practice, 2nd ed., Bhabha Atomic Energy Center, India, 89.

19- El-Kolaly, M.T., Mehany, N.L., Hassan, S.E.M and Ayyoub, S.M., (2006), Arab J. Nucl. Sci. Appl., 39(2),320

20- Edwards,R.: Immunoassay, R. Edwards, John Wiley and Sons, (1996). (ed.), Toronto $3: 15$.

21- Abraham, G. E.: "RIA of steroids in biological fluids". J. of steroid biochem.,Pergamon press., 6: pp. 261- 270, UK, (1975).

22- Bauer, J. D.: "Antigens and antibodies". Clinical Laboratory Methods, $9^{\text {th }}$ edition. The C.V. Mosby Company, London, pp. 411-415, (1982) 
